\title{
9. TRACE METALS (Ba, Sr, Mn, Cu) IN INTERSTITIAL WATERS, LEG 116 $^{1}$
}

\author{
Jacques Boulègue, ${ }^{2}$ Anne-Marie de Kersabiec, ${ }^{2}$ and Francoise Vidot ${ }^{2}$
}

\begin{abstract}
Trace metals, for which we detected no pollution due to drilling and pore-water extraction procedures, are studied in the pore waters of Ocean Drilling Program Leg 116 sediments. Strontium is controlled by dissolution of biogenic carbonates. Barium is controlled by barite and diagenesis. Manganese is controlled by organic matter diagenesis and carbonate. Copper is controlled by hyperfiltration-osmotic effects in alternating clay-sand units. In addition, barium, manganese, and copper are also enriched by upwelling of hot water and its expansion and flow through permeable layers.
\end{abstract}

\section{SAMPLING AND ANALYSES}

We have analyzed the trace metals in interstitial waters collected during Ocean Drilling Program (ODP) Leg 116 to the central Indian Ocean. The samples were collected in acid washed glass vials. Upon sampling, the samples were acidified with $\mathrm{HNO}_{3}$ so as to prevent oxide formation and scavenging of trace metals as well as adsorption on the walls of the vials. Back in the shore-based laboratory, the samples were transferred to teflon bottles. Distilled water treated in the same manner did not show contamination due to storage. Several metals were not analyzed for, as they are found in the metal alloy constituting the pore-water extraction devices available on JOIDES Resolution; these metals are iron, nickel, molybdenum, vanadium, and zinc. The samples were analyzed by atomic absorption and by flameless atomic absorption spectroscopy with Zeeman correction (de Kersabiec et al., 1985). This is preferred to the ICP method, which is sensitive to variations in viscosity leading to nonreproductibility in introduction of sample in the nebulization chamber due to the large variations of sample salinity (Shipboard Scientific Party, 1989 b, c). 3.

The results of the analyses are presented in Tables 1,2, and

\section{DISCUSSION}

\section{Barium}

Among the trace metals analyzed, barium can show variations in concentration as a result of leaching from feldspar in sulfate-depleted waters in the zone of sulfate-reducing microbiological activity. However, barite is employed in the mud used for drilling operations at sea so that specific contamination of pore water during drilling can occur.

The barium concentrations measured in this study are relatively high, so it is first necessary to consider whether or not these are due to contamination during drilling operations. Several points lead us to conclude that the barium data are not due to serious contamination. If contamination were occurring one would expect that the coarser sand-rich layers would be more contaminated. This is not the case with our results. The highest barium values observed are obtained for clay-rich

\footnotetext{
${ }^{1}$ Cochran, J. R., Stow, D.A.V., et al., 1990. Proc. ODP, Sci. Results, 116: College Station, TX, U.S.A. (Ocean Drilling Program).

2 Laboratoire de Géochimie et Métallogénie, CNRS URA 196, UPCM, 4, place Jussieu, 75005 Paris, France.
}

layers where sulfate concentrations decrease to less than millimolar; this is especially clear in samples from Hole 719A such as 116-719A-5X-1, 43-53 cm -17X-4, 140-150 cm-23X-1, $140-150 \mathrm{~cm}$; and $-32 X-2,140-150 \mathrm{~cm}$. It appears that, in the upper parts of holes at Sites 717 and 719, the levels where barium is high are of the same lithology and age. On the other hand, the upper part of holes at Site 718 , where the fluid circulation is believed to be influenced by mixing with downwelling seawater, shows low barium concentrations. Such characteristics, which are consistent with the data obtained on the major elements, would not be possible if data contamination by drilling fluid was effective. Thus we believe that the barium data can be useful in studies of pore-water chemistry.

Three main points are apparent from the barium data of the pore waters at Sites 717, 718, and 719. First, the concentrations of barium are consistently low in the vicinity of the sediments interface. This is exemplified by the data obtained from the top $10 \mathrm{~m}$ of Site 718 .

Second, the barium concentrations increase at levels where the sulfate concentration profiles have a minimum. This is exemplified by the following depths (mbsf):

(i). Site $717: 38 ; 66.5 ; 155 ; 213.5 ; 365.5 ; 479.5 ; 631.5 ; 761.5$;

(ii). Site 718 : $395.3 ; 466.8 ; 564.8$;

(iii). Site $719: 42 ; 152.7 ; 205 ; 292.2$.

Third, and correlated with the previous observation, the barium concentrations decrease where the sulfate concentration profiles have a maximum. This is exemplified by the following depths (mbsf):

(i). Site $717: 325 ; 394 ; 571.4 ; 665$;

(ii). Site 718 : $306.8 ; 418.9 ; 604.3$;

(iii). Site $719: 90.9 ; 181.2 ; 390 ; 455$.

A further observation is that the barium concentrations are generally higher at Site 719 compared with the corresponding levels at Site 717. However, there is good correlation between lows and highs of barium at each site. These features can be related to the fact that the concentrations of sulfate are generally lower at Sites 719 and 717 .

To check whether these characteristics of Ba profiles might be due to variations in sulfate and equilibration with barite, we have compared the ion activity product (I.P.A.) of barite, (a $\mathrm{Ba}^{2+} \times \mathrm{a} \mathrm{SO}_{4}^{2-}$ ) with the equilibrium constant (Ks). In our calculations we have corrected the equilibrium constant of 
Table 1. Trace-metal data for pore waters of holes at Site 717. Depth in mbsf. all concentrations in $\mu \mathrm{M} / \mathrm{kg}$.

\begin{tabular}{crrrr}
\hline $\begin{array}{l}\text { Depth } \\
\text { (mbsf) }\end{array}$ & Sr & Ba & Mn & \multicolumn{1}{c}{ Cu } \\
\hline 6 & 88 & 1.04 & 96.2 & 0.42 \\
38 & 68 & 16.74 & 5.5 & 1.04 \\
66.5 & 80 & 20.01 & 5.9 & 0.24 \\
104.5 & 68 & 9.10 & 12.2 & 0.24 \\
155 & 94 & 22.56 & 3.6 & 1.64 \\
183.5 & 116 & 10.19 & 7.6 & 3.93 \\
213.5 & 114 & 15.65 & 6.0 & 2.99 \\
242 & 105 & 12.74 & 7.4 & 0.94 \\
270.5 & 107 & 5.24 & 2.9 & 0.33 \\
297.5 & 105 & 7.28 & 2.9 & 4.72 \\
325 & 103 & 4.08 & 4.7 & 1.31 \\
365.5 & 126 & 82.97 & 4.2 & 6.75 \\
394 & 121 & 3.06 & 2.6 & 0.39 \\
422.5 & 135 & 8.01 & 4.0 & 7.30 \\
449.5 & 139 & 4.16 & 5.2 & 2.20 \\
479.5 & 146 & 17.47 & 5.2 & 11.43 \\
508 & 137 & 4.51 & 6.1 & 1.24 \\
571.4 & 139 & 1.82 & 6.8 & 11.02 \\
598.5 & 139 & 30.13 & 7.1 & 3.40 \\
631.5 & 160 & 19.65 & 7.0 & 2.68 \\
665 & 178 & 3.64 & 10.2 & 1.50 \\
723.5 & 183 & 11.35 & 10.5 & 15.42 \\
761.5 & 210 & 13.10 & 8.0 & 8.31 \\
788.5 & 228 & 8.37 & 9.8 & 11.77 \\
823.2 & 224 & 9.82 & 25.5 & 10.45 \\
\hline & & & & \\
\hline
\end{tabular}

barite (Church, 1970) for in-situ temperature and pressures. The activity coefficients and the ion association effects are those considered by Church (1970). The computation was not done for samples where $\mathrm{SO}_{4}^{2-}=0 \mathrm{M}$ on the basis of the shipboard analysis. All points correspond to high concentrations of $\mathrm{Ba}^{2+}$, as noted earlier.

The comparisons of ion activity product (I.A.P.) and Ks (Figs. 1-3) show that equilibrium with barite is nearly reached in the majority of the samples. The fact that barium concentrations are higher at Site 719 than at Site 717 is also reflected in higher I.A.P. at Site 719 in spite of lower sulfate values. The difference between the sites may be due to local effects of diagenesis or to circulation of fluids. At both sites the levels with high barium and high I.A.P. are also those where the alkalinity had a local maximum (Shipboard Scientific Party, 1989c). Low chlorinity occurs in clay-rich layers, most probably due to osmosis and hyperfiltration effects (Shipboard Scientific Party, 1989a, b, c). At both sites, the only exception is in the top 60 meters, where the maxima of barium corresponds to a layer where calciummagnesium carbonate should precipitate by replacement of $\mathrm{CaCO}_{3}$. In this case barium is almost excluded from the solid solution and should accumulate in the pore waters.

At several intervals where $\mathrm{Ba}^{2+}$ is high and $\mathrm{SO}_{4}^{2-}$ minimal, the surrounding pore waters also have quite high $\mathrm{Ba}^{2+}$. This suggests specific source levels for $\mathrm{Ba}^{2+}$, and diffusion outward from these levels. The separation of these levels can be assessed only roughly, because pore waters were sampled only every $30 \mathrm{~m}$. At Site 717 the peaks at $66.5,155$, $213.5,365.5$, and $631.5 \mathrm{mbsf}$ seem to correspond to diffusion on a $50-\mathrm{m}$ scale. The diffusion coefficient of $\mathrm{Ba}^{2+}$ can be taken as $15( \pm 5) \times 10^{-6} \mathrm{~cm}^{2} / \mathrm{s}$ and the porosity is given by shipboard measurement; this enables us to compute a time scale for diffusion from the source in the range of $5 \times 10^{4} \mathrm{yr}$. This indicates a recent phenomenon if the source-diffusion argument is valid. The same order of magnitude is obtained for calculations based on the distribution of $\mathrm{Ba}^{2+}$ maxima of Sites 718 and 719 .

However, at Site 718 the maxima of $\mathrm{Ba}^{2+}$ do not all show the same associated characteristics. In two cases $(90.5$ and
Table 2. Trace-metal data for pore waters at Site 718. Depth in mbsf; all concentrations in $\mu \mathrm{M} / \mathrm{kg}$.

\begin{tabular}{|c|c|c|c|c|}
\hline $\begin{array}{l}\text { Depth } \\
\text { (mbsf) }\end{array}$ & $\mathrm{Sr}$ & $\mathrm{Ba}$ & $\mathrm{Mn}$ & $\mathrm{Cu}$ \\
\hline 0.5 & 98 & 0.87 & 4.8 & 1.05 \\
\hline 1.5 & 91 & 1.45 & 28.3 & 0.38 \\
\hline 3 & 89 & 0.84 & 49.2 & 0.39 \\
\hline 4.5 & 89 & 1.28 & 58.1 & 1.81 \\
\hline 6 & 82 & 0.70 & 40.0 & 0.39 \\
\hline 7.4 & 83 & 1.05 & 34.5 & 5.98 \\
\hline 7.5 & 88 & 0.80 & 30.0 & 3.15 \\
\hline 7.8 & 87 & 0.94 & 33.8 & 9.07 \\
\hline 9.0 & 82 & 0.70 & 34.9 & 0.35 \\
\hline 31.3 & 82 & 2.33 & 9.8 & 0.78 \\
\hline 90.5 & 135 & 2.77 & 89.8 & 8.18 \\
\hline 107.3 & 100 & 1.20 & 38.8 & 0.05 \\
\hline 124.8 & 91 & 1.44 & 31.5 & 4.15 \\
\hline 143.8 & 98 & 2.00 & 23.5 & 14.95 \\
\hline 182.8 & 103 & 3.88 & 12.4 & 5.92 \\
\hline 191.3 & 135 & 2.91 & 9.3 & 10.23 \\
\hline 238.8 & 137 & 8.19 & 5.8 & 4.41 \\
\hline 278.7 & 137 & 9.81 & 10.0 & 1.50 \\
\hline 308.8 & 137 & 2.98 & 11.0 & 2.05 \\
\hline 343.3 & 148 & 7.20 & 8.9 & 8.11 \\
\hline 395.3 & 178 & 18.19 & 8.1 & 5.04 \\
\hline 418.9 & 189 & 4.83 & 10.9 & 4.97 \\
\hline 428.8 & 181 & 4.95 & 11.8 & 18.73 \\
\hline 438.8 & 189 & 13.39 & 13.7 & 3.27 \\
\hline 495.7 & 154 & 4.38 & 7.7 & 7.71 \\
\hline 525.3 & 154 & 12.70 & 7.9 & 8.22 \\
\hline 584.8 & 192 & 15.28 & 8.4 & 8.17 \\
\hline 593.3 & 183 & 25.40 & 10.7 & 14.74 \\
\hline 804.3 & 183 & 5.53 & 13.3 & 14.40 \\
\hline 847.3 & 192 & 5.09 & 13.1 & 22.85 \\
\hline 877.3 & 201 & 13.39 & 13.1 & 18.0 \\
\hline 704.3 & 219 & 4.73 & 13.7 & 8.31 \\
\hline 770.8 & 248 & 4.33 & 28.2 & 10.39 \\
\hline 800 & 256 & 9.48 & 8.1 & 15.93 \\
\hline 830 & 257 & 8.08 & 8.4 & 35.41 \\
\hline 858.3 & 205 & 20.09 & 7.3 & 2.01 \\
\hline 920 & 274 & 8.33 & 6.4 & 4.91 \\
\hline 935 & 258 & 2.17 & 8.2 & 8.80 \\
\hline 952 & 233 & 2.82 & 8.8 & 12.48 \\
\hline
\end{tabular}

Table 3. Trace-metal data for pore waters at Site 719. Depth in mbsf; all concentrations in $\mu \mathrm{M} / \mathrm{kg}$.

\begin{tabular}{crrrr}
\hline $\begin{array}{c}\text { Depth } \\
\text { (mbsf) }\end{array}$ & \multicolumn{1}{c}{$\mathrm{Sr}$} & \multicolumn{1}{c}{$\mathrm{Ba}$} & \multicolumn{1}{c}{ Mn } & \multicolumn{1}{c}{$\mathrm{Cu}$} \\
\hline 3 & 100 & 1.07 & 167.9 & 0.66 \\
42 & 80 & 25.47 & 4.1 & 3.10 \\
60 & 84 & 18.31 & 6.1 & 2.83 \\
90.9 & 82 & 8.41 & 4.9 & 14.79 \\
118.2 & 89 & 13.14 & 4.7 & 2.52 \\
119.7 & 84 & 13.97 & 3.2 & 13.16 \\
152.7 & 112 & 68.05 & 20.9 & 27.35 \\
181.2 & 98 & 4.98 & 10.5 & 22.16 \\
205 & 114 & 39.15 & 6.1 & 23.83 \\
233 & 114 & 20.44 & 6.6 & 3.15 \\
263.7 & 137 & 99.85 & 8.4 & 12.46 \\
292.2 & 132 & 153.93 & 5.5 & 13.99 \\
320.7 & 128 & 31.15 & 9.3 & 1.97 \\
352.2 & 132 & 11.29 & 5.6 & 10.23 \\
390 & 160 & 5.81 & 7.5 & 4.72 \\
435 & 164 & 17.98 & 8.0 & 4.89 \\
455 & 180 & 4.91 & 9.7 & 5.82 \\
\hline & & & & \\
\hline
\end{tabular}

$856.3 \mathrm{mbsf}$ ) they correspond to high concentrations of $\mathrm{SO}_{4}$, $\mathrm{Mg}$, and $\mathrm{Ca}$; I.A.P. is also much larger than Ks. As discussed elsewhere (Shipboard Scientific Party, 1989), these levels correspond to areas where mixing is occurring between hot upwelling water and pore water or, possibly, seawater. In this case one would expect that the hot temperature member has 


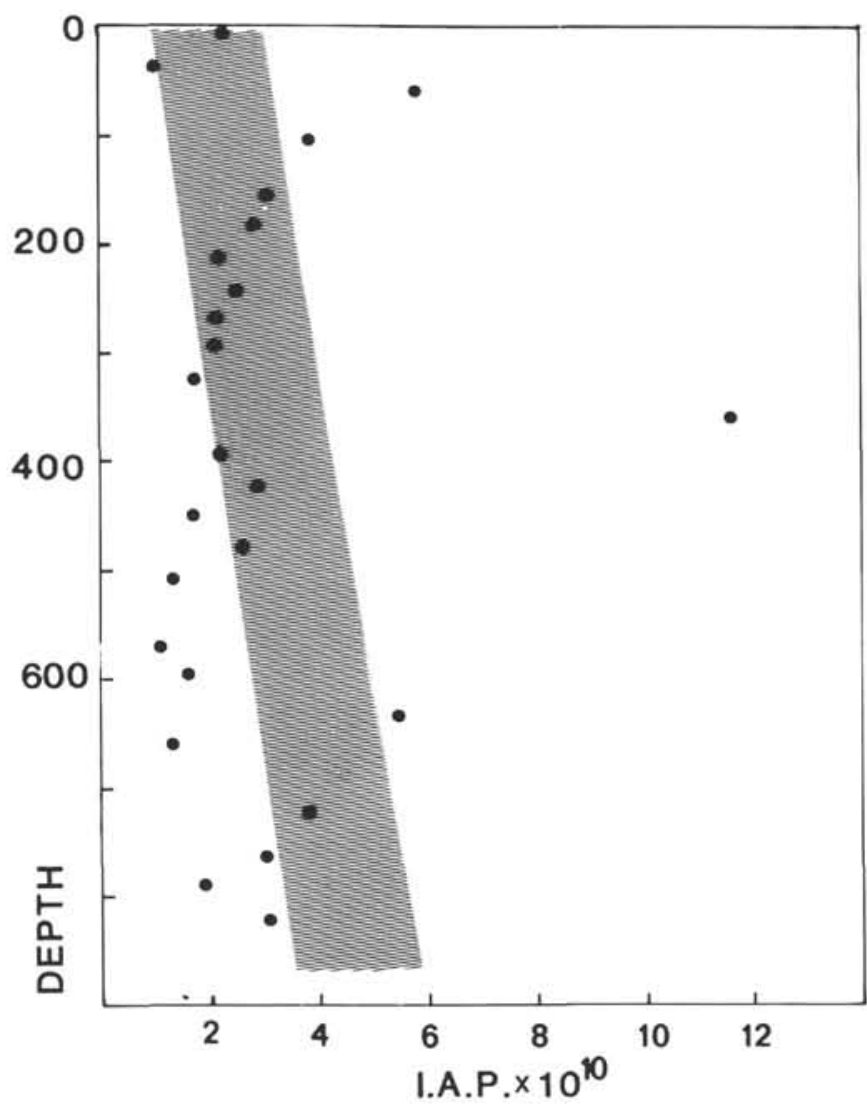

Figure 1. Ion Activity Product (I.A.P.) of $\mathrm{BaSO}_{4}$ in Site 717 pore waters. The dashed area corresponds to equilibrium at in-situ pressure and temperature. Depths are meters below seafloor.

depleted sulfate and very high barium concentrations as typically found in hydrothermal waters. Hence the mixing will result in oversaturation of sulfate with respect to barite.

\section{Strontium}

The strontium profiles of the three sites drilled have a common characteristic: the concentration of strontium increases with depth, with few variations from a linear trend (Figs. 4, 5, and 6). The slopes of the linear increases of $\mathrm{Sr}^{2+}$ with depth are $d \mathrm{Sr} / d z(\mathrm{mM} / \mathrm{km}): 0.16$ for Site $717 ; 0.19$ for Site 718 and 0.20 for Site 719 . This behavior contrasts with that of calcium. Only in the top 50 mbsf of Sites 717 and 719 is there a clear correlation between strontium and calcium. This behavior of strontium can be simply explained by dissolution of biogenic carbonate giving dissolved strontium and inhibition of substitution of calcium by strontium in the neoformed carbonates. Using arguments developed by Baker et al. (1982) it is possible to compute the likely range of concentrations for strontium in the deepest sediments, upon dissolution of biogenic carbonate. These concentrations are $22 \mathrm{mM}$ for Site 717 , $23 \mathrm{mM}$ for Site 718 , and $19 \mathrm{mM}$ for Site 719 , values which compare very closely with these measured at 800,900 , and 400 mbsf, respectively.

Both strontium and barium concentrations increase more rapidly with depth at Site 719 than at Site 717 , although both sites have similar lithologies.

\section{Manganese}

The profiles of $\mathrm{Mn}^{2+}$ vs. depth are given in Figures 7, 8, and 9. In all profiles the values obtained in the top $10 \mathrm{~m}$ are very high: $9.6 \times 10^{-5} \mathrm{M}$ at Site 717,3 to $5.6 \times 10^{-5} \mathrm{M}$ at Site 718 and $17 \times 10^{-5} \mathrm{M}$ at Site 719 . This can be explained by the effect of organic matter diagenesis in creating reducing conditions not far below the sediment-seawater interface. Another common characteristic of all profiles is that there is a tendency for $\mathrm{Mn}^{2+}$ to increase with depth, although with some scatter in values. These are generally higher at Site $718(10 \pm 3 \mu \mathrm{M})$ than at Site $719(7 \pm 3 \mu \mathrm{M})$ or Site $717(5 \pm 3 \mu \mathrm{M})$.

There is no correlation of high manganese concentrations with levels where $\mathrm{SiO}_{2}$ is increasing; thus the dissolution of biogenic silica is probably not the source of manganese.

Some values are higher than the mean values discussed above. At 104.5 mbsf in Site 717 , the increase in manganese corresponds to an increase in calcium and a decrease in magnesium that has been attributed to the transformation of $\mathrm{CaCO}_{3}$ to $(\mathrm{Ca}-\mathrm{Mg}) \mathrm{CO}_{3}$ (Shipboard Scientific Party, 1989a). The increase in manganese may be due to lack of incorporation of manganese in $(\mathrm{Ca}-\mathrm{Mg}) \mathrm{CO}_{3}$. At $152.7 \mathrm{mbsf}$, Site 719 , the increase of manganese is correlated with an increase of alkalinity in a clay layer; manganese being also well correlated with alkalinity in the top 200 mbsf of Site 719. This may be attributed to the reducing role of organic matter during its diagenesis.

At 823.2 mbsf at Site 717 and $770.0 \mathrm{mbsf}$ at Site 718 there is a strong increase of manganese. At these levels it was inferred that upwelling and lateral expansion of hot water was occurring (Shipboard Scientific Party, 1989a, b). High manganese concentration and increased alkalinity would be expected if the hot-water component is derived from the deepest sediment, due to the reducing effect of organic matter. However, the increase in calcium and $\mathrm{SiO}_{2}$ would also suggest interaction with the basaltic crust (Shipboard Scientific Party, 1989a, b).

The manganese concentration at $90.5 \mathrm{mbsf}$ in Site 718 is by far the highest of this hole. At this level it was inferred that there was expansion of hot water (Shipboard Scientific Party, $1989 \mathrm{~b})$. The concentration of manganese is another argument favoring this interpretation.

\section{Copper}

Copper profiles are similar at all three sites; they show a large variability in concentrations, high values corresponding to levels with lower chloride and salinity, and low values corresponding to levels with higher chloride and salinity. This result is interesting, because among the elements we have analyzed (major and trace components) this is the only one to show such a clear anticorrelation with chloride and salinity.

From a simple point of view this suggests that a chloride phase may control the concentration of copper. Atacamite, $\mathrm{Cu}_{2} \mathrm{Cl}(\mathrm{OH})_{3}$ is a possible candidate. However, equilibrium calculations can be made taking the solubility product of atacamite $\mathrm{Ks}=\left(\mathrm{aCu}^{2+}\right)^{2} \cdot \mathrm{aCl}^{-} \cdot\left(\mathrm{aH}^{+}\right)^{-3}=10^{7.34}$ and taking into account activity coefficients as well as complex formation for $\mathrm{Cu}^{2+}: \mathrm{CuCO}_{3}{ }^{0}, \mathrm{CuOH}^{+}, \mathrm{CuCl}^{+}$(Sevéque et al., 1985). The computations show that the ratio of the I.A.P. to Ks is larger than 100 in $90 \%$ of the samples, so that a large oversaturation with respect to atacamite is obtained. Atacamite, therefore, is most probably not controlling copper concentrations in the pore waters.

It has been suggested that copper concentration in the pore waters of hemipelagic sediments could be controlled by $\mathrm{Cu}$ accommodation in authigenic clay materials (Petersen et al., 1986). We have seen that the chloride profiles in Leg 116 sites could be explained by hyperfiltration-osmotic effects, which imply replacement of sodium and calcium by potassium and magnesium in interlayer clays (Shipboard Scientific Party, $1989 a, b, c)$. In this case one should expect $\mathrm{Cu}^{2+}$ to substitute with $\mathrm{Mg}^{2+}$ in the interlayer space of clay minerals. Because 


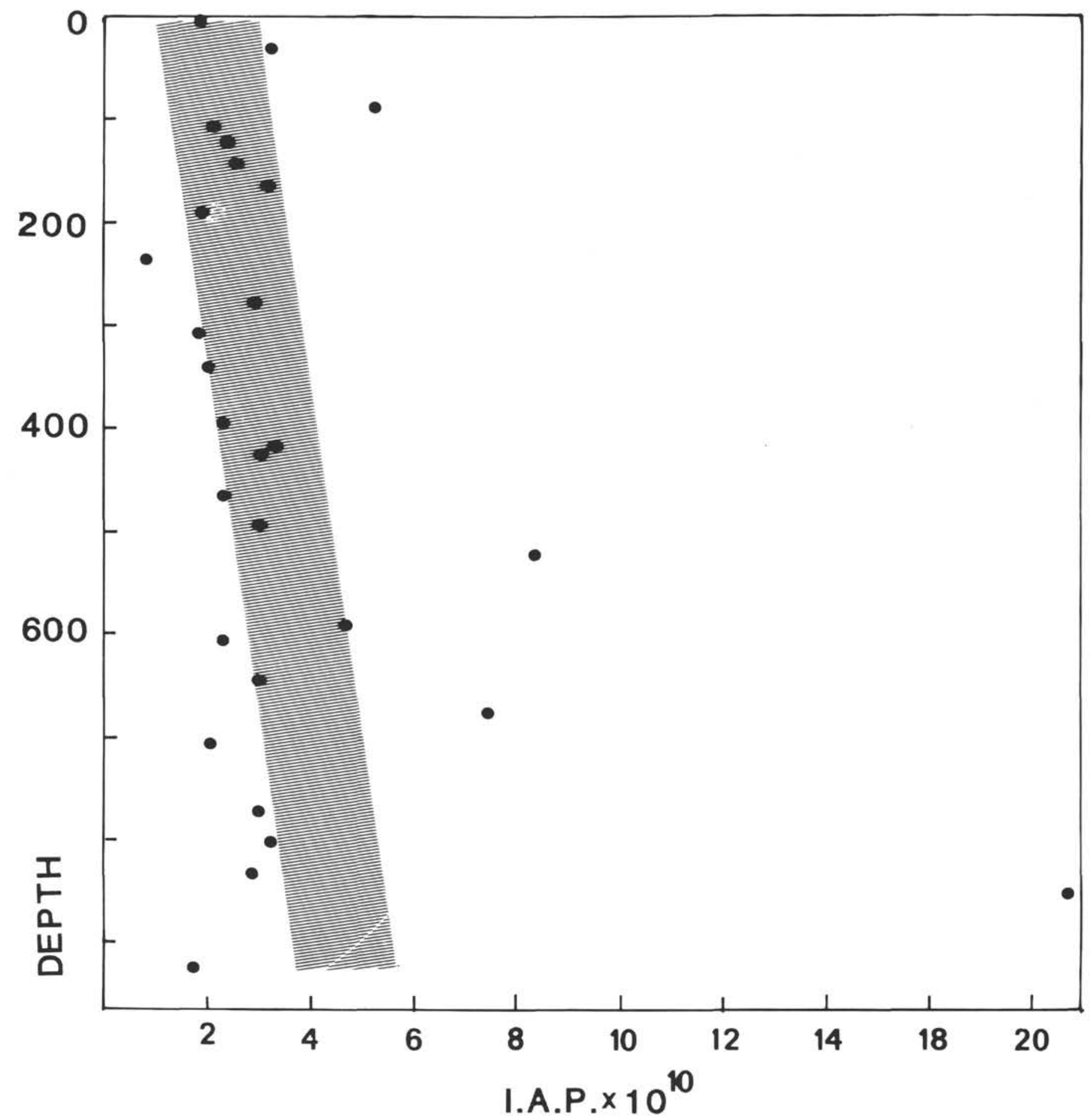

Figure 2. Ion Activity Product of $\mathrm{BaSO}_{4}$ in Site 718 pore waters. The dashed area corresponds to equilibrium at in-situ pressure and temperature.

sodium and calcium behave similarly from the point of view of membrane effects, one can expect copper to accumulate where the salinity has decreased.

In addition, a large copper concentration is found at Site 718 at 830 mbsf in an area where upwelling and expansion of hot water is inferred. We have seen that this movement of fluid can induce precipitation of an assemblage of carbonate, silica, and sulfide (Boulégue and Mariotti, in press and this volume). The sulfides are $\mathrm{FeS}_{2}$ and $\mathrm{CuFeS}_{2}$. The fact that high concentrations of dissolved copper are still found in a porous layer at Site 718 shows that there is still some hot fluid activity. However, because the maxima obtained for manganese and barium are not at the same depth the maxima for $\mathrm{Cu}$ a complex fluid circulation pattern must exist.

\section{CONCLUSIONS}

Due to the procedures of pore-water extraction on board JOIDES Resolution several trace metals cannot be assessed because they are present in the extraction equipment: these are iron, nickel, cobalt, molybdenum, vanadium, and zinc. Some other trace metals can be assessed if the drilling operation does not cause contamination. We have shown that 


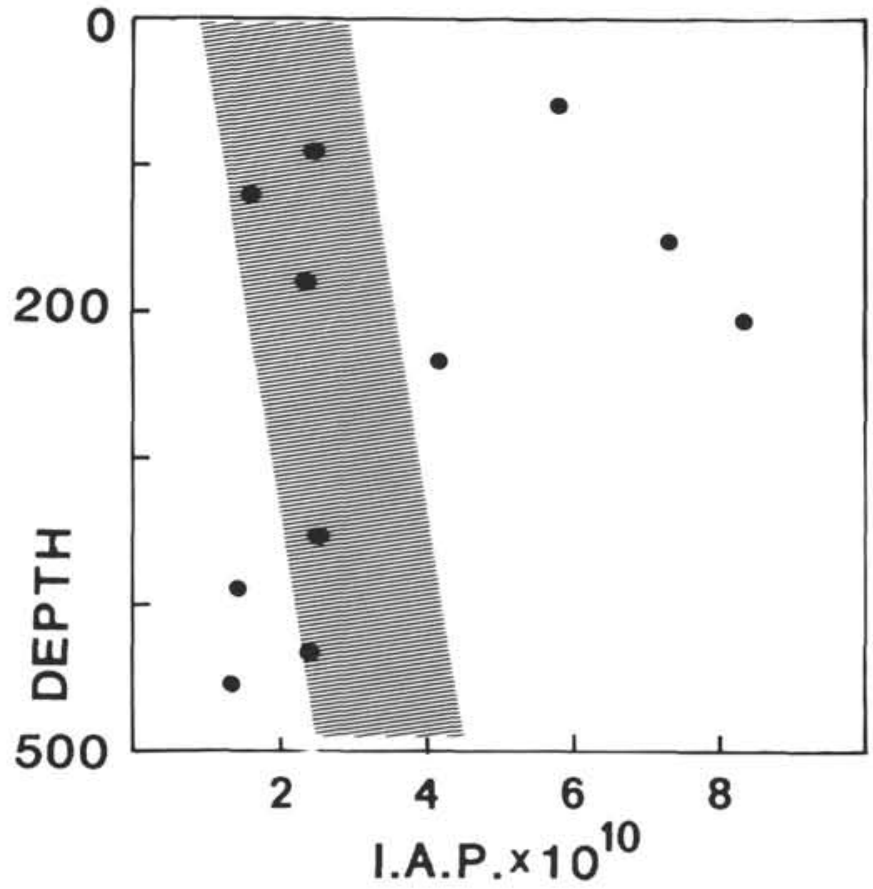

Figure 3. Ion Activity Product of $\mathrm{BaSO}_{4}$ in Site 719 pore waters. The dashed area corresponds to equilibrium at in-situ pressure and temperature.

this can be done for barium, strontium, manganese, and copper. Strontium in the pore waters of Leg 116 sites is controlled by dissolution of biogenic carbonates. Barium is controlled by organic matter diagenesis as well as by carbonate. Copper is controlled by inclusion in the interlayer sites of clays and by accompanying membrane-osmotic effects in compacting clay-sand sequences. In addition, the upwelling of hot water and its lateral expansion in permeable layers bring locally high concentrations of barium, manganese, and copper in the pore waters.

\section{REFERENCES}

Baker, P. A., Griekes, J. M., and Elderfield, H., 1982. Diagenesis of carbonates in deep-sea sediments: evidence from $\mathrm{Sr} / \mathrm{Ca}$ ratios and interstitial dissolved $\mathrm{Sr}^{2+}$ data. J. Sediment. Petrol., 52:71-82.

Boulégue, J., and Mariotti, A., in press. Carbonate cements and fluid circulation in intraplaque deformation. Chem. Geol.

Church, T. M., 1970. Marine Barite [Ph.D. dissert.]. Univ. of California at San Diego.

De Kersabiec, A. M., Blanc, G., and Pinta, M., 1985. Water analysis by Zeeman Atomic Absorption Spectrometry. Fresinius Z. Anal. Chem., 322:731-735.

Petersen, T. F., Vogel, J. S., and Southern, J. R., 1988. Copper and manganese in hemipelagic sediments at $21^{\circ} \mathrm{N}$, East Pacific Rise: diagenetic contrasts. Geochim. Cosmochim. Acta, 50:2019-2031.

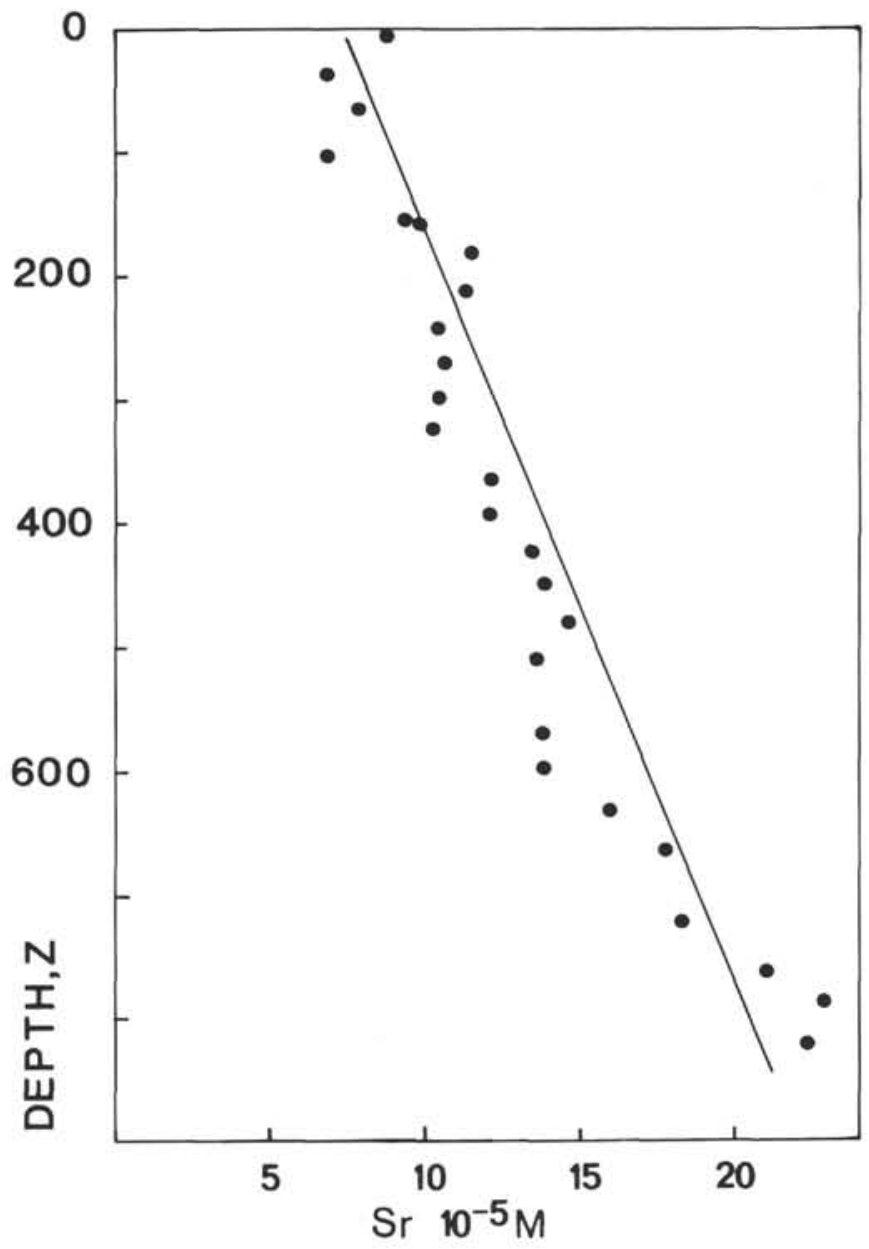

Figure 4. Strontium in Site 717 pore waters. The line corresponds to $d \mathrm{Sr} / d z=0.16 \mathrm{mM} / \mathrm{km}$.

Sevéque, J. L., Oustriére, P., Criaud, A., 1985. WATRAZ, programme de calcul d'équilibre dans les eaux. Rep. BRGM, 85 SGN 061 GMX.

Shipboard Scientific Party, 1989a. Site 717: Bengal Fan. In Cochran, J. R., Stow, D.A.V., et al., Proc. ODP, Init. Repts., 116: College Station, TX (Ocean Drilling Program), 45-90.

Shipboard Scientific Party, 1989b. Site 718: Bengal Fan. In Cochran, J. R., Stow, D.A.V., et al., Proc. ODP, Init. Repts., 116: College Station, TX (Ocean Drilling Program), 91-154.

Shipboard Scientific Party, 1989c. Site 719: Bengal Fan. In Cochran, J. R., Stow, D.A.V., et al., Proc. ODP, Init. Repts., 116: College Station, TX (Ocean Drilling Program), 155-196.

Date of initial receipt: 5 February 1990

Date of acceptance: 5 February 1990

Ms 116B-132 


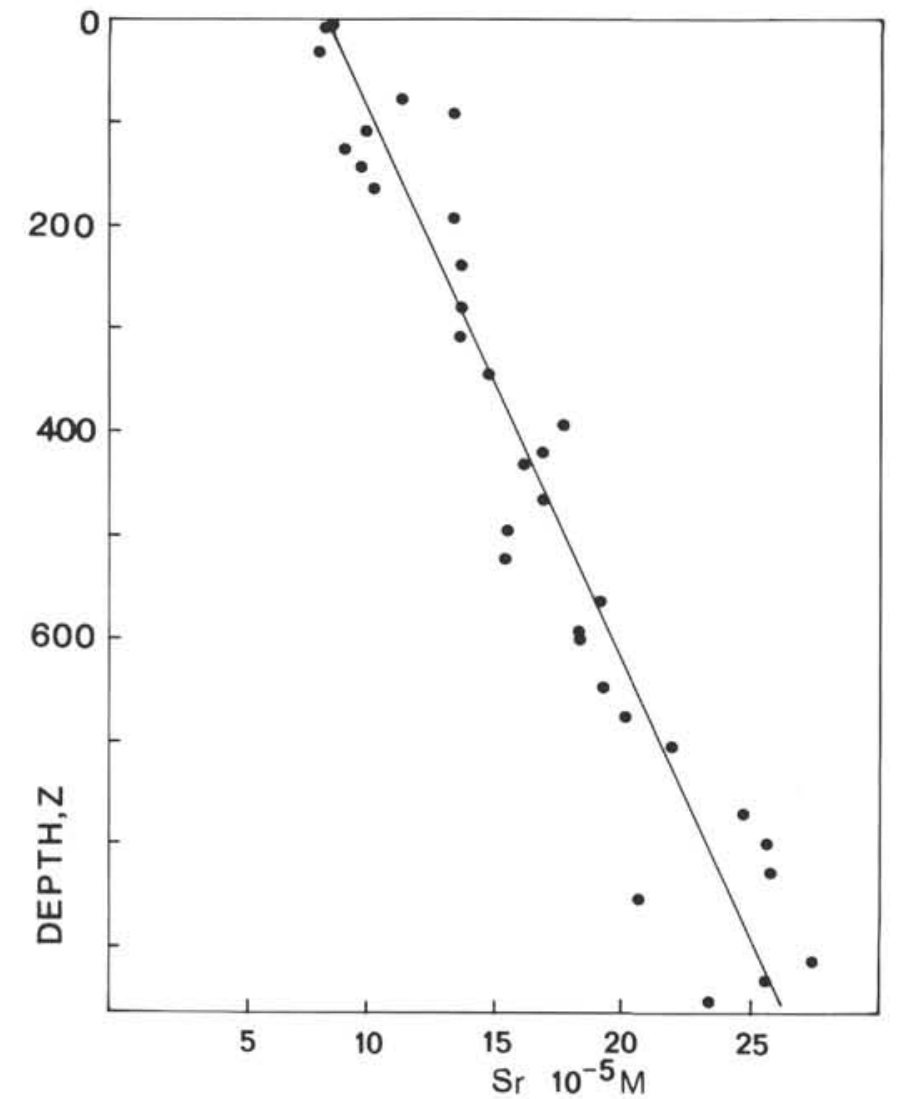

Figure 5. Strontium in Site 718 pore waters. The line corresponds to $d \mathrm{Sr} / d z=0.19 \mathrm{mM} / \mathrm{km}$.

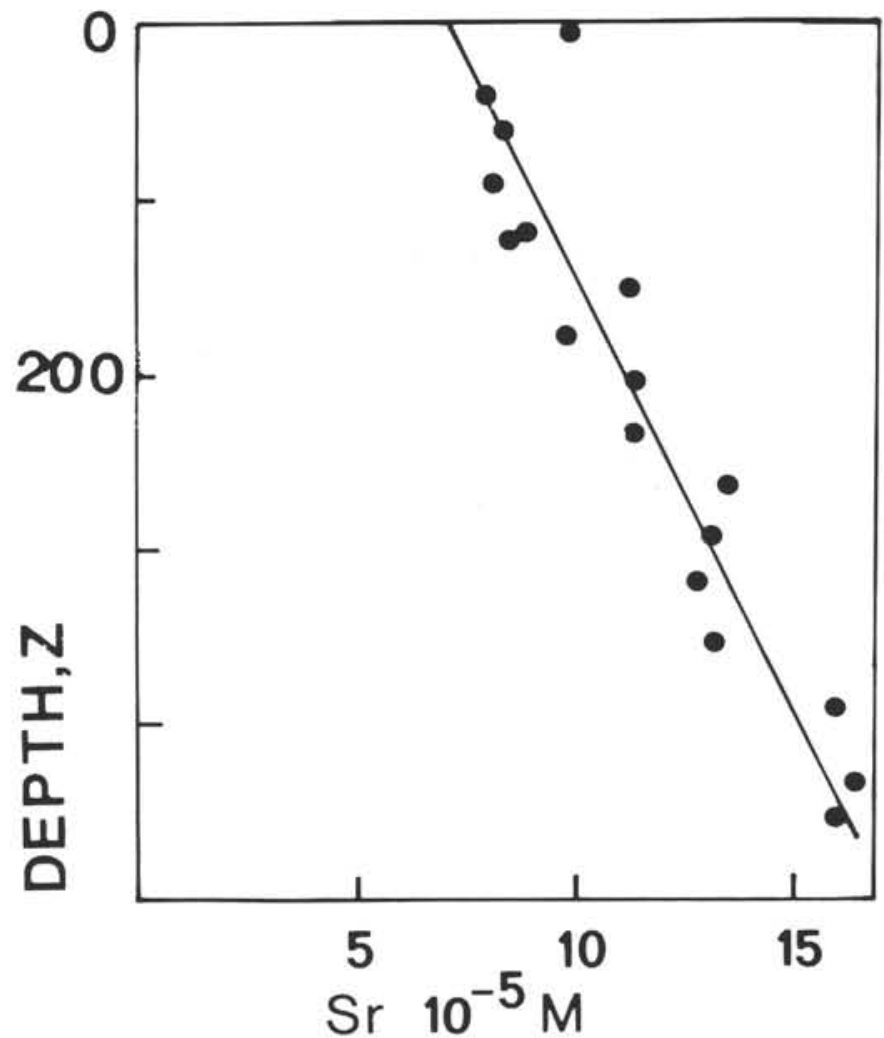

Figure 6. Strontium in Site 719 pore waters. The line corresponds to $d \mathrm{Sr} / d z=0.20 \mathrm{mM} / \mathrm{km}$. 


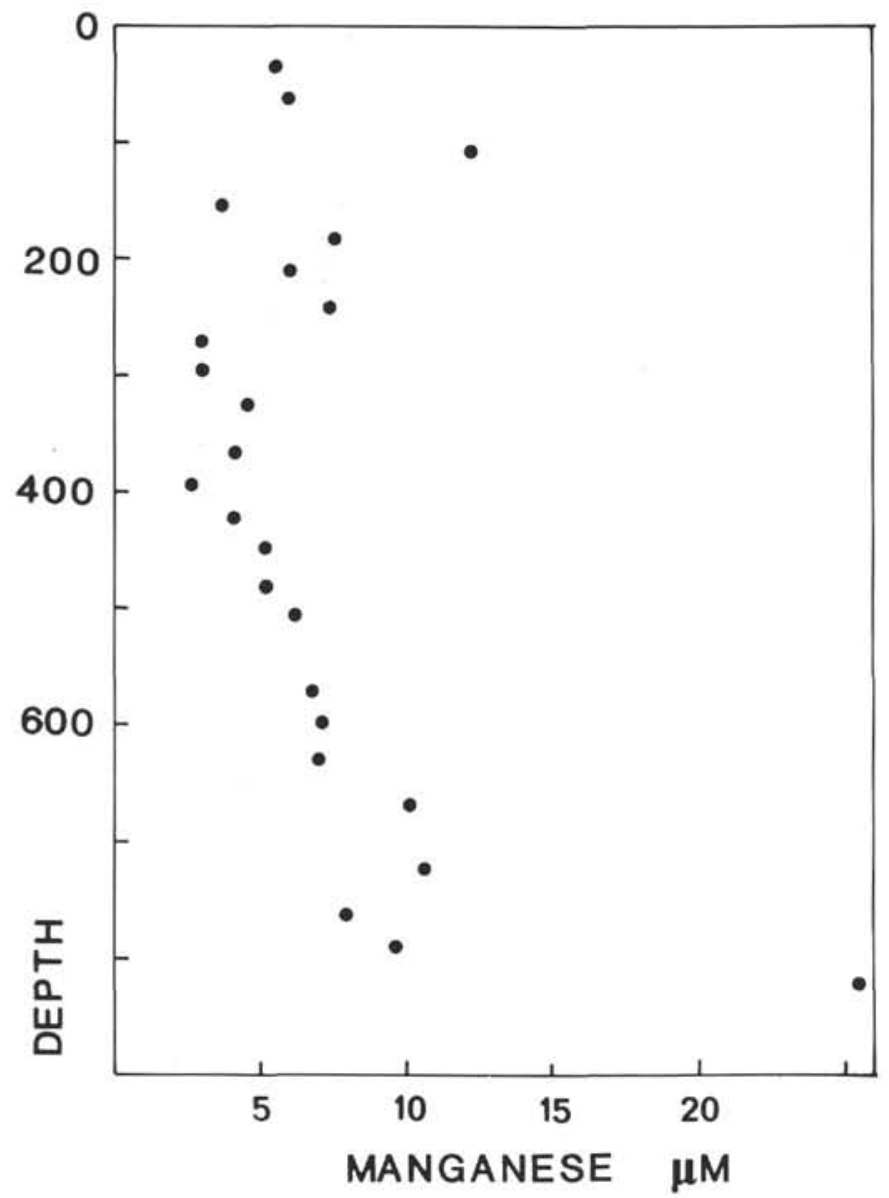

Figure 7. Manganese in Site 717 pore waters. 


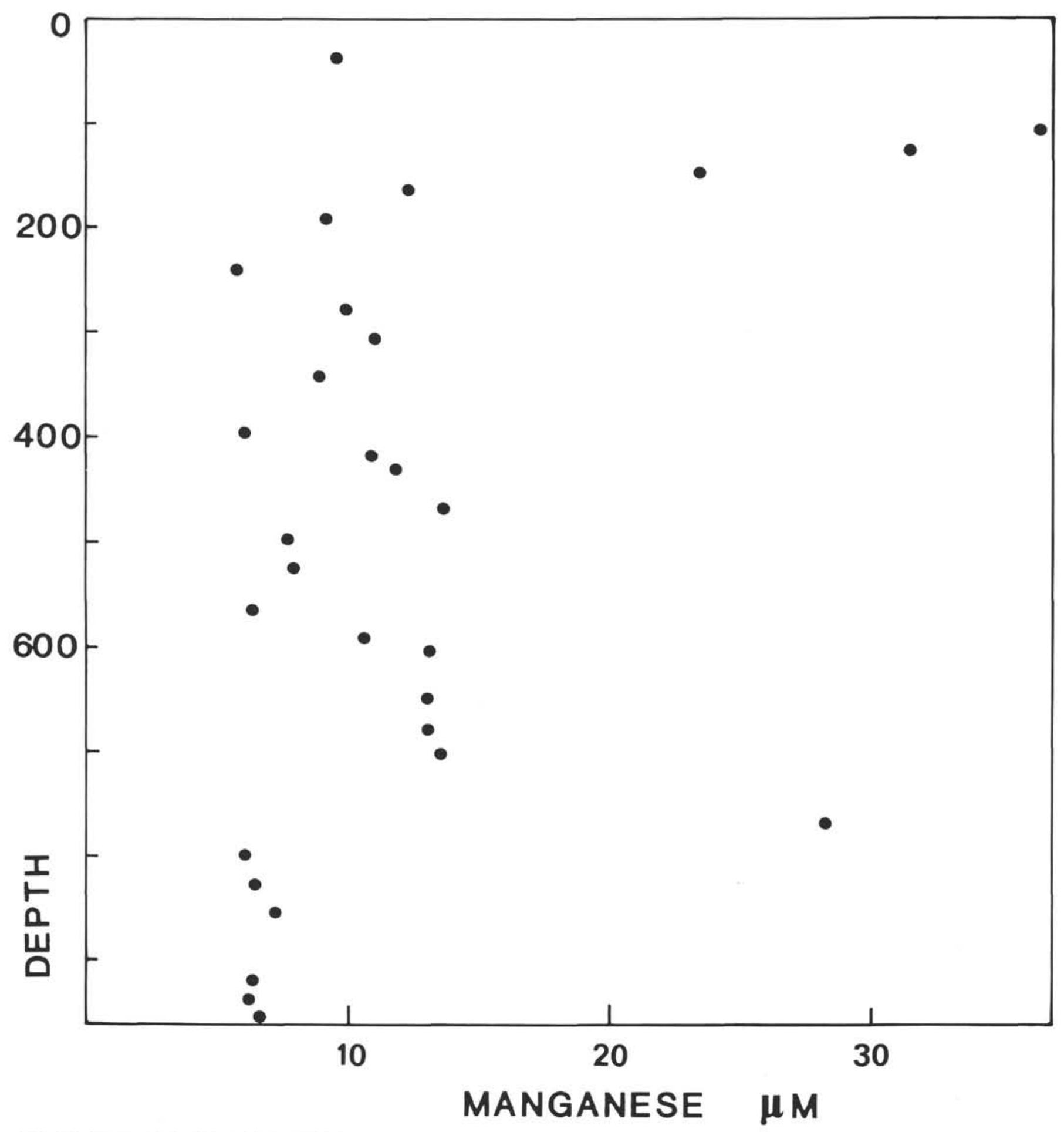

Figure 8. Manganese in Site 718 pore waters. 


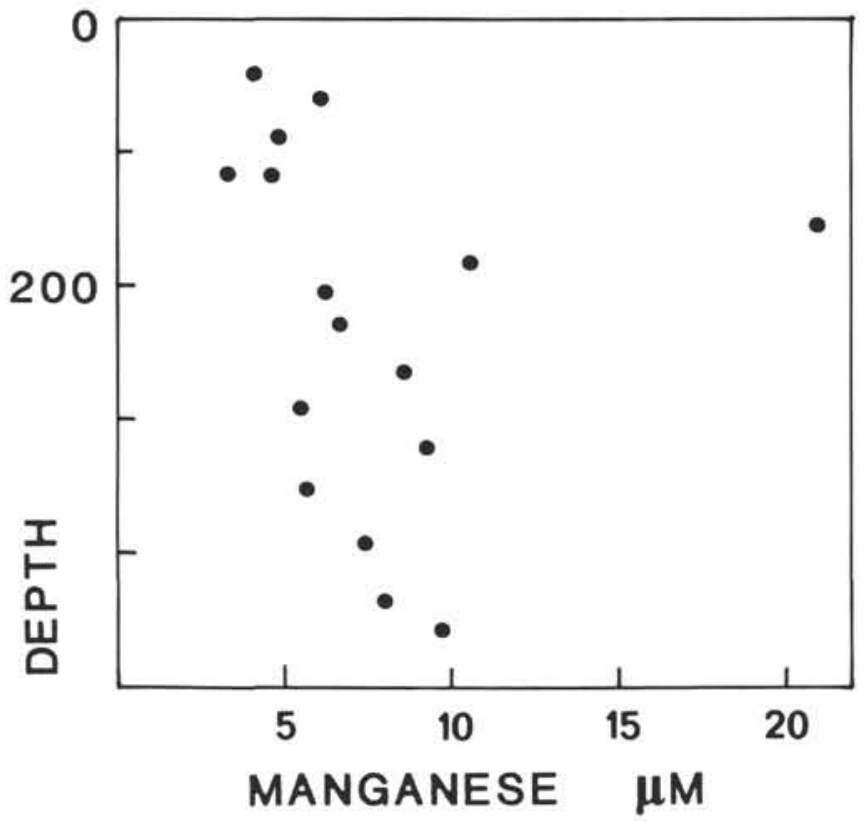

Figure 9. Manganese in Site 719 pore waters. 